\title{
ANALISIS MINAT BELAJAR SISWA KELAS XI MIA PADA MATA PELAJARAN KIMIA
}

\author{
K. L. Hemayanti ${ }^{1}$, I. W. Muderawan², I. N. Selamat ${ }^{3}$ \\ 123 Universitas Pendidikan Ganesha, Indonesia
}

\author{
A R T I C L E I N F O \\ Article history: \\ Received 22 Februari 2020 \\ Received in revised form \\ 25 Februari 2020 \\ Accepted 29 Maret 2020 \\ Available online 30 April \\ 2020
}

Kata Kunci:

minat belajar, mata

pelajaran kimia.

\begin{abstract}
A B S T R A K
Tujuan penelitian ini adalah mendeskripsikan (1) minat belajar siswa pada mata pelajaran kimia dan (2) faktor-faktor yang memengaruhi minat belajar siswa pada mata pelajaran kimia di SMAS Laboratorium Undiksha Singaraja. Penelitian ini merupakan penelitian deskriptif kualitatif dengan pendekatan fenomenologi. Jumlah sampel yang digunakan untuk mendapatkan data tentang minat belajar siswa dalam penelitian adalah sebanyak 45 orang siswa kelas XI MIA SMAS Laboratorium Undiksha Singaraja yang diambil dengan teknik sensus, sedangkan jumlah sampel yang digunakan untuk mendapatkan data faktor-faktor yang memengaruhi minat belajar adalah 15 orang siswa yang diambil dengan teknik purposive sampling. Hasil penelitian menunjukkan bahwa profil minat belajar kimia siswa kelas XI MIA SMAS Laboratorium Undiksha Singaraja adalah 38\% siswa yang tergolong tinggi, 51\% siswa yang tergolong sedang, dan $11 \%$ siswa yang tergolong rendah. Minat belajar kimia siswa di SMAS Laboratorium Undiksha Singaraja dipengaruhi oleh faktor internal dan faktor eksternal. Faktor internal yang memengaruhi minat belajar kimia adalah keingintahuan, cita-cita, motivasi, serta intelegensi sedangkan faktor eksternal yang memengaruhi yakni lingkungan keluarga, cara guru mengajar, teman sebaya, dan bahan pelajaran.
\end{abstract}

\begin{abstract}
The purpose of this study is to describe (1) interest in learning of student's chemistry subject matter and (2) the factors that affect student's interest in learning chemistry subject matter at Laboratory SMAS Undiksha Singaraja. This research is a qualitative descriptive study with a phenomenological approach. The number of samples used to get data about student's learning interest in the study were 45 students of class XI MIA at Laboratory SMAS Undiksha Singaraja taken by census techniques, while the number of samples used to obtain data on factors affect learning interest were 15 students were taken by purposive sampling techniques. The results showed that the profile of student's interest in learning chemistry subject matter of class XI MIA at Laboratory SMAS Undiksha Singaraja in general was 38\% students classified as high, $51 \%$ students classified as moderate, and $11 \%$ students classified as low. Student's interest in learning chemistry subject matter at Laboratory SMAS Undiksha Singaraja was affected by internal factors and external factor. Internal factors that affect the interest in learning chemistry was curiosity, future goals, motivation, and intelligence mean while external factors affecting was family environment, teachers, peers, and teaching materials.
\end{abstract}

Keywords: subject learning interest, chemistry subject matter.

\section{Pendahuluan}

Pendidikan secara sederhana dapat diartikan sebagai usaha manusia untuk membina kepribadiannya sesuai dengan nilai-nilai di dalam masyarakat dan kebudayaannya. Menurut UU No. 20 Tahun 2003 tentang Sistem Pendidikan Nasional pada pasal 1 (2003:6) dijelaskan bahwa: pendidikan adalah usaha sadar terencana untuk mewujudkan suasana belajar dan proses pembelajaran agar siswa secara aktif dapat mengembangkan potensi dirinya untuk memiliki kekuatan spiritual keagamaan, pengendalian diri, kepribadian, kecerdasan, akhlak mulia, serta keterampilan yang diperlukan dirinya, masyarakat, bangsa, dan negaranya. Pendidikan memiliki peran penting untuk menciptakan manusia yang berkualitas dan berpotensi karena pendidikan merupakan sarana utama dalam upaya meningkatkan

\footnotetext{
1 Corresponding author.

E-mail: liahemayanti@gmail.com (K. L. Hemayanti)
} 
sumber daya manusia. Menyadari pentingnya sektor pendidikan, maka setiap negara berlomba-lomba untuk meningkatkan kualitas pendidikan agar dapat bersaing pada dunia global. Pada era globalisasi, perkembangan Ilmu Pengetahuan dan Teknologi (IPTEK) berkembang dengan sangat pesat, salah satunya adalah ilmu kimia.

Ilmu kimia merupakan salah satu rumpun dari Ilmu Pengetahuan Alam (IPA). Sebagai salah satu rumpun dari IPA, ilmu kimia dipandang sebagai proses dan produk. Sebagai proses, dapat diartikan sebagai kegiatan ilmiah untuk menyempurnakan pengetahuan maupun untuk menemukan pengetahuan baru. Sebagai produk diartikan sebagai hasil proses yang berupa fakta, konsep, prinsip, dan hukum serta teori temuan ilmuan kimia. Permendiknas (2006) menyatakan bahwa mata pelajaran kimia di SMA/MA bertujuan agar siswa memiliki kemampuan yaitu membentuk sikap positifterhadap kimia dan menyadari keteraturan dan keindahan alam serta mengagungkan kebesaran Tuhan Yang Maha Esa, memupuk sikap ilmiah yaitu jujur, objektif, terbuka, ulet, kritis, dan dapat bekerja sama dengan orang lain, memperoleh pengalaman dalam menerapkan metode ilmiah melalui percobaan atau eksperimen, meningkatkan kesadaran tentang terapan kimia yang dapat bermanfaat dan juga merugikan bagi individu, masyarakat, dan lingkungan serta menyadari pentingnya mengelola dan melestarikan lingkungan dan kesejahteraan masyarakat, dan memahami konsep, prinsip, hukum, dan teori kimia serta saling keterkaitannya dan penerapannya untuk menyelesaikan masalah dalam kehidupan sehari-hari dan teknologi. Hal tersebut menunjukkan bahwa ilmu kimia sangat penting untuk dipelajari di sekolah.

Namun pada kenyataannya, pada umumnya siswa SMA kurang tertarik pada pelajaran kimia. Penelitian sebelumnya yang dilakukan oleh Akram, dkk. (2017) menyatakan bahwa tidak semua siswa sekolah menengah atas memiliki minat belajar yang tinggi. Penelitian sebelumnya yang dilakukan oleh Marsita, dkk. (2010) juga menyatakan bahwa penyebab utama kesulitan belajar siswa dalam mempelajari kimia adalah kurangnya minat siswa pada saat mempelajari kimia sehingga membuat hasil belajar siswa tersebut rendah.

Berdasarkan studi pendahuluan pada 6 Mei 2019 di SMAS Laboratorium Undiksha Singaraja, didapatkan informasi bahwa masih banyak siswa yang mendapat nilai rendah. Hal ini terlihat dari hasil Penilaian Akhir Semester (PAS) siswa kelas X MIA semester genap tahun pelajaran 2018/2019 secara keseluruhan berada dibawah kriteria ketuntasan minimal (KKM) sekolah yaitu didapatkan sebanyak 88,89\% siswa tidak tuntas dengan kriteria ketuntasan minimal (KKM) 70 dan siswa kelas XI MIA smester ganjil tahun pelajaran 2019/2020 secara keseluruhan berada di bawah kriteria ketuntasan minimal (KKM) sekolah yaitu didapatkan sebanyak 91,11\% siswa tidak tuntas dengan kriteria ketuntasan minimal (KKM) 75. Lebih lanjut, guru kimia menegaskan bahwa sebagian besar siswa SMAS Laboratorium Undiksha Singaraja tidak antusias dalam mengikuti pelajaran kimia. Siswa kurang antusias dalam menjawab pertanyaan yang diberikan oleh guru dan kurang antusias dalam mengerjakan soal-soal yang diberikan pada saat pelajaran kimia. Selanjutnya peneliti melakukan wawancara kepada beberapa siswa di SMAS Laboratorium Undiksha Singaraja pada tanggal 27 Mei 2019. Hasil wawancara menunjukkan bahwa siswa SMAS Laboratorium Undiksha Singaraja kurang tertarik terhadap mata pelajaran kimia karena bagi siswa tersebut mata pelajaran kimia terlalu sulit dan susah untuk dipahami. Beberapa orang siswa yang menyatakan bahwa menyukai pelajaran kimia pada materi tertentu saja karena materi tersebut lebih mudah untuk dipahami. Pernyataan tersebut menunjukkan bahwa minat belajar siswa SMAS Laboratorium Undiksha Singaraja terhadap mata pelajaran kimia masih tergolong rendah. Penelitian sebelumnya yang dilakukan oleh Putri (2017) menyatakan siswa kurang tertarik pada pelajaran kimia karena kebanyakan pelajaran kimia bersifat abstrak dan susah dipahami.

Keberhasilan siswa dalam belajar dapat dipengaruhi oleh beberapa faktor yakni faktor internal yaitu faktor yang berasal dari dalam diri siswa dan faktor eksternal yaitu faktor yang berasal dari luar diri siswa. Faktor internal terdiri atas motivasi, perhatian, minat, bakat, intelegensi, dan cara belajar. Faktor eksternal terdiri atas lingkungan keluarga, lingkungan sekolah, dan lingkungan masyarakat. Minat belajar merupakan salah satu faktor internal yang dapat memengaruhi prestasi belajar siswa sehingga analisis terhadap faktor-faktor yang memengaruhi minat belajar siswa penting untuk dilakukan. Penelitian yang telah dilakukan oleh Adodo \& Gbore (2012) menyatakan bahwa minat menjadi salah satu aspek terpenting dalam mendorong keberhasilan pembelajaran karena akan memunculkan ingatan yang baik bagi siswa. Ketika siswa kehilangan minat dalam pembelajaran maka materi pelajaran tersebut akan mudah untuk dilupakan.

Pengembangan minat belajar kimia yang baik perlu ditumbuhkan pada siswa. Mengingat pentingnya minat belajar dalam proses pembelajaran, guru harus memperhatikan dan mengembangkan minat belajar kimia siswa. Hal tersebut dikarenakan minat dapat mendorong siswa untuk lebih giat dalam belajar kimia. Berdasarkan permasalahan yang telah dipaparkan di atas, peneliti tertarik untuk meneliti lebih jauh mengenai profil minat belajar siswa kelas XI MIA SMAS Laboratorium Undiksha Singaraja dan 
faktor-faktor yang mempengaruhi minat belajar siswa kelas XI MIA terhadap pelajaran kimia. Oleh karena itu, peneliti melakukan penelitian yang berjudul "Analisis Minat Belajar Siswa Kelas XI MIA Terhadap Mata pelajaran Kimia Di SMAS Laboratorium Undiksha Singaraja."

Penelitian ini bertujuan untuk (1) mendeskripsikan profil minat belajar siswa kelas XI MIA SMAS Laboratorium Undiksha Singaraja pada mata pelajaran kimia; (2) mendeskripsikan faktor-faktor yang memengaruhi minat belajar siswa kelas XI MIA SMAS Laboratorium Undiksha Singaraja pada mata pelajaran kimia.

\section{Metode}

Penelitian ini termasuk penelitian kuaitatif dengan pendekatan fenomenologi. Subjek penelitian ini adalah guru kimia, wakil kepala sekolah sarana dan prasarana, dan siswa kelas XI MIA SMAS Laboratorium Undiksha Singaraja. Teknik pengumpulan data yang digunakan adalah studi dokumen, observasi, kuesioner, dan wawancara. Teknik studi dokumen dilakukan untuk memeroleh data berupa nama-nama siswa, penilaian akhir semester genap tahun pelajaran 2018/2019 dan penilaian akhir semester ganjil tahun pelajaran 2019/2020. Observasi digunakan untuk mendapatkan data terkait proses pembelajaran dikelas. Wawancara digunakan untuk mendapatkan data terkait faktor-faktor yang memengaruhi minat belajar kimia. Kuesioner digunakan untuk mendapatkan data terkait profil minat belajar kimia siswa.

Analisis data dalam penelitian ini menggunakan deskriptif interpretatif. Analisis data nilai UAS dianalisis secara deskriptif kualitatif, analisis data kuesioner dianalisis dengan deskriptif kualitatif, analisis data hasil observasi dilakukan secara deskriptif, serta analisis data hasil wawancara dianalisis secara deskriptif interpretatif.

\section{Hasil dan pembahasan}

1) Minat Belajar Siswa pada Mata Pelajaran Kimia

Minat belajar kimia siswa dilihat dari lima aspek, yaitu perhatian, perasaan senang, ketertarikan, partisipasi, dan kepuasaan. Minat belajar siswa dikumpulkan melalui kuesioner minat. Perolehan skor minat belajar siswa melalui kuesioner dikategorikan menjadi lima, yaitu sangat tinggi, tinggi, sedang, rendah, dan sangat rendah. Minat Belajar Siswa kelas XI MIA SMAS Laboratorium Undiksha Singaraja adalah 38\% siswa tergolong memiliki minat belajar tinggi, 51\% siswa memiliki minat belajar sedang, dan $11 \%$ siswa memiliki minat belajar rendah. Pada aspek perhatian siswa kelas XI MIA pada mata pelajaran kimia di SMAS Laboratorium Undiksha dikatagorikan sedang, aspek perasaan senang dikatagorikan sedang, aspek ketertarikan dikatagorikan sedang, aspek partisipasi dikatagorikan sedang, dan di aspek kepuasan dikatagorikan tinggi. Jadi Minat Belajar Siswa kelas XI MIA pada mata pelajaran kimia di SMAS Laboratorium Undiksha Singaraja dikatagorikan memiliki minat belajar yang sedang.

Berikut ini disajikan hasil analisis kelima aspek minat siswa kelas XI MIA SMAS Laboratorium Undiksha Singaraja disajikan pada Tabel 1.

Tabel 1. Distribusi Total Rerata Skor Hasil Kuesioner Masing-Masing Aspek

\begin{tabular}{ccccccc}
\hline No. & Kategori & Perhatian & $\begin{array}{c}\text { Perasaan } \\
\text { Senang }\end{array}$ & $\begin{array}{c}\text { Aspek (\%) } \\
\text { Ketertarikan }\end{array}$ & Partisipasi & Kepuasan \\
\hline 1 & Sangat Tinggi & 4 & 0 & 0 & 7 & 16 \\
2 & Tinggi & 43 & 11 & 22 & 18 & 40 \\
3 & Sedang & 44 & 65 & 62 & 60 & 33 \\
4 & Sangat Rendah & 9 & 11 & 16 & 11 & 11 \\
5 & Rendah & 0 & 13 & 0 & 4 & 0 \\
\hline
\end{tabular}

2) Faktor-faktor yang Memengaruhi Minat Belajar Siswa

Minat belajar kimia siswa di SMAS Laboratorium Undiksha Singaraja dipengaruhi oleh dua faktor yaitu faktor internal dan faktor eksternal. Faktor internal yang memengaruhi minat belajar siswa dalam mata pelajaran kimia adalah keingintahuan, cita-cita, motivasi, dan intelegensi. Selanjutnya, faktor eksternal yang memengaruhi minat belajar kimia siswa adalah bahan pelajaran, keluarga, guru, dan teman sebaya.

Keingintahuan merupakan salah satu faktor yang memengaruhi minat belajar siswa SMA Laboratorium Undiksha Singaraja terhadap mata pelajaran kimia. Pada penelitian ini ditemukan bahwa 
siswa yang memiliki minat belajar tinggi dipengaruhi oleh rasa ingin tahu yang besar dari siswa itu sendiri saat mempelajari kimia. Siswa kelas XI MIA yang memiliki keingintahuan yang besar saat belajar kimia disebabkan karena kesadaran mereka akan pentingnya mempelajari kimia. Mereka menyadari bahwa hampir semua benda yang ada di sekitar mereka mengandung bahan-bahan kimia seperti peralatan mandi, obat-obatan, kosmetik, bahan makanan maupun minuman yang sering dikonsumsi juga berisikan bahan-bahan kimia. Oleh karena itu, dengan mempelajari kimia mereka akan dapat mengetahui manfaat, dampak dan bahaya dari bahan-bahan tersebut terhadap kesehatan.

Selain keingintahuan, minat belajar kimia siswa kelas XI MIA juga dipengaruhi oleh cita-cita. Pada penelitian ini ditemukan bahwa siswa kelas XI MIA terdorong memiliki minat belajar tinggi terhadap mata pelajaran kimia karena mereka berkeinginan untuk menjadi seseorang yang berkecimpung dalam bidang kimia. Mereka beranggapan bahwa untuk menjadi seseorang yang ahli dalam kimia, tentu diperlukan pemahaman yang besar terhadap ilmu kimia. Ilmu kimia banyak diterapkan dalam kehidupan sehari-hari seperti dalam bidang farmasi, kedokteran, pertanian, dan lain sebagainya. Dalam bidang farmasi ilmu kimia dimanfaatkan sebagai penyediaan obat-obatan yang dapat digunakan dalam bidang kedokteran dengan tujuan untuk menyembuhkan pasien yang mengidap suatu penyakit. Pembuatan obat-obatan ini didasarkan pada hasil riset terhadap proses dan reaksi kimia dari bahan-bahan kimia yang berkhasiat. Selain itu, dalam bidang pertanian ilmu kimia sering digunakan untuk pembuatan pupuk dan pestisida. Pembuatan pupuk ini bertujuan untuk mengembalikan kesuburan tanah, sedangkan pestisida bertujuan untuk mengatasi hama-hama yang menyerang tanaman. Dengan mengetahui manfaat dan aplikasi dari ilmu kimia tersebut dalam kehidupan sehari-hari, maka akan dapat semakin mendorong siswa untuk mewujudkan cita-cita yang ingin mereka raih khususnya dalam bidang kimia.

Motivasi merupakan salah satu faktor internal yang memengaruhi minat belajar siswa. Pada penelitian ini ditemukan bahwa siswa kelas XI MIA memiliki motivasi yang tinggi baik motivasi dalam belajar maupun motivasi untuk memperoleh hasil belajar yang baik. Siswa memiliki motivasi yang tinggi dalam belajar kimia disebabkan karena ingin melanjutkan pendidikan ke jenjang selanjutnya yang berhubungan dengan kimia sehingga siswa tersebut tekun dan berungguh-sungguh dalam mempelajari materi kimia, selain itu siswa yang memiliki minat belajar kimia yang tinggi juga termotivasi untuk memiliki hasil belajar kimia yang baik dan memuaskan. Penelitian ini juga didukung oleh penelitian sebelumnya yang dilakukan oleh Jirana, dkk. (2015) yang menyatakan bahwa aspek psikologi memiliki pengaruh yang paling besar terhadap minat belajar mahasiswa biologi yaitu sebesar 47,06\%. Aspek psikologi yang dimaksud adalah motivasi, perhatian, dan ketertarikan mahasiswa dalam belajar biologi.

Intelegensi mempunyai pengaruh yang besar terhadap minat belajar siswa. Dalyono (2004) yang menyatakan bahwa seseorang yang memiliki intelegensi baik umumnya mudah belajar dan hasilnya pun cenderung baik. sebaliknya orang yang intelegensinya rendah cenderung mengalami kesukaran dalam belajar, lambat berpikir, sehingga prestasi belajar siswa menjadi rendah. Pada penelitian ini ditemukan bahwa siswa kelas XI MIA SMAS Laboratorium Undiksha Singaraja kesulitan dalam menangkap dan memahami materi kimia sehingga siswa tersebut tidak menyukai kimia. Penelitian ini didukung oleh penelitian sebelumnya yang dilakukan oleh Passler, dkk. (2015), menyatakan bahwa intelegensi memiliki pengaruh besar terhadap minat belajar siswa. Intelegensi dapat memprediksi kinerja siswa dan intelegensi dapat menentukan apa yang menjadi potensi siswa untuk belajar sesuatu.

Faktor eksternal yang memengaruhi minat belajar siswa kelas XI MIA terhadap mata pelajaran kimia adalah bahan pelajaran. Pada penelitian ini ditemukan bahwa siswa Kelas XI MIA terdorong untuk memiliki minat rendah dalam mata pelajaran kimia karena mereka beranggapan bahwa materi-materi kimia itu sebagian besar sulit untuk dipahami. Kesulitan mereka dalam mempelajari kimia disebabkan karena kebanyakan materi kimia bersifat abstrak. Hal serupa juga dikemukakan oleh Kean dan Middlecamp (dalam Rumansyah, 2002) mereka mengatakan bahwa salah satu kesulitan siswa dalam mempelajari kimia adalah karena hampir sebagian materi kimia bersifat abstrak. Kesulitan siswa dalam memahami materi kimia yang bersifat abstrak dikarenakan karena kekurangan siswa dalam membayangkan materi yang tidak bisa diamati secara langsung. Selain itu, Kean dan Middlecamp (dalam Rumansyah, 2002) juga mengemukakan bahwa salah satu faktor yang menyebabkan siswa mengalami kesulitan dalam belajar kimia adalah materi pembelajaran kimia bersifat berurutan artinya beberapa materi kimia harus dipelajari dengan urutan tertentu karena menjadi prasyarat untuk memahami materi selanjutnya. Oleh karena itu, sangat penting bahwa siswa harus memahami dengan baik keseluruhan materi-materi kimia yang telah diajarkan karena akan dapat membantu siswa untuk memahami materi selanjutnya.

Peran keluarga juga memengaruhi minat belajar siswa kelas XI MIA SMAS Laboratorium Undiksha Singaraja dalam mata pelajaran kimia. Dalam penelitian ini ditemukan bahwa siswa kelas XI MIA yang memiliki minat belajar tinggi dalam mata pelajaran kimia mengatakan bahwa peranan keluarga dapat 
mendorong siswa untuk menyukai mata pelajaran kimia. Peranan keluarga seperti menemani siswa saat belajar, memberi pengarahan, memberi nasehat, memberi fasilitas yang dibutuhkan serta dukungandukungan lain akan dapat meningkatkan minat belajar siswa terhadap mata pelajaran kimia. Selain itu, dalam penelitian ini juga ditentukan bahwa siswa kelas XI MIA yang memiliki minat belajar rendah terhadap mata pelajaran kimia disebabkan oleh kurangnya dukungan dan arahan dari orang tua terhadap siswa ketika sedang belajar kimia di rumah.

Peran guru juga memengaruhi minat belajar siswa kelas XI MIA SMAS Laboratorium Undiksha Singaraja terhadap mata pelajaran kimia. Pada penelitian ini ditemukan bahwa cara mengajar guru dapat memengaruhi minat belajar siswa kelas XI MIA SMAS Laboratorium Undiksha Singaraja terhadap mata pelajaran kimia. Guru yang menggunakan cara mengajar yang tepat dan sesuai dengan karakteristik siswa di kelas dapat membuat siswa menjadi tertarik mengikuti pembelajaran sehingga dapat meningkatkan minat belajar kimia siswa. Hal ini diperkuat dengan hasil wawancara terhadap siswa kelas XI MIA yang mengatakan bahwa yang mendorong mereka menyukai mata pelajaran kimia adalah cara guru dalam menyampaikan materi pelajaran. Selain itu, dalam penelitian ini juga ditemukan bahwa siswa kelas XI MIA yang memiliki minat rendah terhadap mata pelajaran kimia disebabkan oleh kurang terjalinnya hubungan yang harmonis antara guru dan siswa. Mereka mengatakan bahwa sikap guru yang tegas sehingga membuat mereka menjadi takut dan tertekan pada saat mengikuti pembelajaran kimia, pada akhirnya membuat mereka menjadi tidak menyukai mata pelajaran kimia.

Teman sebaya juga dapat memengaruhi minat belajar kimia siswa. Teman sebaya adalah anak-anak atau remaja yang memiliki usia atau tingkat kematangan yang kurang lebih sama (Santrock, 2007). Dalam penelitian ini ditemukan bahwa siswa kelas XI MIA yang memiliki minat belajar tinggi mengemukakan bahwa melihat teman-teman yang pintar dan berhasil mendapatkan hasil belajar yang baik, membuat mereka terdorong untuk belajar lebih giat agar bisa mendapatkan nilai yang lebih tinggi dari siswa lain. Selain itu, dalam penelitian ini juga ditemukan bahwa siswa kelas XI MIA yang memiliki minat belajar kimia rendah disebabkan karena pengaruh teman sebaya. Hal ini diperkuat dengan hasil wawancara siswa yang menyatakan bahwa mereka kurang tertarik terhadap pembelajaran kimia karena setiap pembelajaran kimia berlangsung siswa selalu diajak bermain dan mengobrol oleh siswa lainnya akibatnya siswa menjadi kurang fokus mengikuti pembelajaran dan berdampak pada kurangnya pemahaman siswa terhadap materi yang sedang disampaikan. Apabila tidak memahami materi yang sedang dijelaskan maka akan membuat siswa menjadi kurang memahami materi selanjutnya yang pada akhirnya akan membuat siswa menjadi kesulitan dalam mempelajari kimia.

\section{Simpulan dan saran}

Adap Berdasarkan hasil temuan yang diperoleh selama penelitian dan pembahasan sebelumnya dapat disimpulkan sebagai berikut.

1. Profil minat belajar siswa kelas XI MIA SMAS Laboratorium Undiksha Singaraja adalah 38\% siswa yang tergolong memiliki minat belajar kimia tinggi dengan jumlah 17 orang, 51\% siswa yang tergolong memiliki minat belajar kimia sedang dengan jumlah 23 orang, dan 11\% siswa yang tergolong memiliki minat belajar kimia rendah dengan jumlah 5 orang. Jadi minat belajar siswa kelas XI MIA SMAS Laboratorium Undiksha Singaraja pada mata pelajaran kimia dikategorikan sedang.

2. Minat belajar kimia siswa kelas XI MIA SMAS Laboratorium Undiksha Singaraja dipengaruhi oleh dua faktor yaitu faktor internal dan faktor eksternal. Faktor internal yang memengaruhi minat belajar siswa terhadap mata pelajaran kimia adalah keingintahuan, cita-cita, motivasi, dan intelegensi sedangkan faktor eksternal yang memengaruhi minat belajar siswa terhadap mata pelajaran kimia adalah lingkungan keluarga, guru, teman sebaya, dan bahan pelajaran.

Untuk meningkatkan minat belajar siswa pada mata pelajaran kimia, penulis menyarankan beberapa hal sebagai berikut.

1. Guru hendaknya menerapkan metode pembelajaran yang disesuaikan dengan karakteristik dari mata pelajaran kimia itu sendiri. Dengan demikian, akan dapat membantu guru dalam menumbuhkan minat belajar siswa terhadap mata pelajaran kimia.

2. Guru hendaknya memperhatikan faktor-faktor yang memengaruhi minat belajar siswa pada mata pelajaran kimia sehingga dapat meningkatkan minat belajar siswa pada mata pelajaran kimia. 


\section{Daftar Rujukan}

Adodo, S. O. \& Gbore, L. O. 2012. Prendicition of attitude and interest of science students of different ability on their academic performance in basic science. International Journal of psychology and Counselling, 4(6), 68-72.

Akram, T. M., Ijaz, A., \& Ikram, H. 2017. Exploring the Factors Responsible for Declining Students Interest in Chemistry. International Journal of Information and Education Technology, 7(2), 88-94.

A'yuningsih, D. Q., Suardana, I. N., \& Suwenten, I. M. (2017). Penerapan Model Pembelajaran Kooperatif Tipe TGT (Teams Games Tournament) Untuk Meningkatkan Motivasi Dan Hasil Belajar Peserta Didik. Jurnal Pendidikan Kimia Indonesia, 1(2), 37-47.

Budiariawan, I. P. (2019). Hubungan Motivasi Belajar Dengan Hasil Belajar Pada Mata Pelajaran Kimia. Jurnal Pendidikan Kimia Indonesia, 3(2), 103-111.

Dalyono. M. 2004. Psikologi Pendidikan. Jakarta: Rineka Cipta.

Departemen Pendidikan Nasional, 2003. Undang-Undang Nomor 20 Tahun 2003, Tentang Sistem Pendidikan Nasional, Jakarta: Depdiknas.

Depdiknas. 2006. Permendiknas No. 22 Tahun 2006 Tentang Standar Isi. Jakarta: Depdiknas.

Jayadiningrat, M. G., Tika, I. N., \& Yuliani, N. P. (2017). Meningkatkan Kesiapan Dan Hasil Belajar Siswa Pada Pembelajaran Kimia Dengan Pemberian Kuis Di Awal Pembelajaran. Jurnal Pendidikan Kimia Indonesia, 1(1), 7-12.

Jirana, Nur, dan Nurmiati. 2015. Faktor-faktor yang Memengaruhi Kesulitan dan Minat Belajar Mahasiswa Jurusan Pendidikan Biologi Universitas Sumatera Barat. Jurnal Saintifik, 1, 89-94.

Marsita., Priatmoko., dan Kusuma., 2010. Analisis Kesulitan Belajar Kimia Siswa SMA dalam Memahami Materi Larutan Penyangga dengan Menggunakan Two-tier Multiple-Choice Diagnostic Instrument, Jurnal inovasi pendidikan kimia 4:512-520.

Passler, K., Beinicke, A., \& Hell, B. 2015. Interests and intelligence: A meta-analysis. Intelligence, 50, 30-51. http://doi.org/10.1177/1069072710382615.

Putri, G.A.P.W.A. 2017. Minat Belajar Siswa SMA Negeri 1 Sukasada terhadap Mata Pelajaran Kimia. Skripsi (tidak diterbitkan). Singaraja: Universitas Pendidikan Ganesha.

Rumansyah 2002. Penerapan Metode Latihan Berstruktur dalam Meningkatkan Pemahaman Siswa terhadap Konsep Kimia. Tersamaan pada http//www.org/mod/data/view.php?d=3\&rid=24 (diakses pada tanggal 15 Agustus 2016).

Santrock, J. W. 2007. Psikologi Perkembangan. Edisi 11 Jilid 1. Jakarta: Erlangga. 